Egypt. Acad. J. Biolog. Sci., 5(2): 19-27 (2013)

Email: egyptianacademic@yahoo.com

Received: 25 / 4 / 2013
C. Physiology \& Molecular Biology

ISSN: 2090-0767

www.eajbs.eg.net

\title{
The Activity of Some Detoxification Enzymes in Spodoptera Littoralis (Boisd.) Larvae (Lepidoptera - Noctuidae) Treated With Two Different Insect Growth Regulators
}

\author{
Reda F. A. Bakr ${ }^{1 \& 4}$; Mona F. Abd Elaziz ${ }^{2}$;Nehad M, El-barky ${ }^{2}$ Mohamed H. Awad ${ }^{3}$ \\ and Hisham M. E. Abd El-Halim2. \\ 1- Entomology Department - Faculty of Science- Ain Shams University \\ 2- Entomology Department - Faculty of Science- Benha University \\ 3- Zoology Department - Faculty of Science- Benha University \\ 4- Biology Department, Faculty of Science, King Khalid University, Abha, Saudi Arabia \\ e-mail: redabakr55@gmail.com
}

\begin{abstract}
The susceptibility to IGRs, moulting hormone agonist, mimic (tebufenozide) and chitin synthesis inhibitors match (lufenuron) was studied in the $2^{\text {nd }}$ and $4^{\text {th }}$ larval instars of the cotton leafworm Spodoptera littoralis (Bosid). Obtained results revealed that match was the more toxic against $2^{\text {nd }}$ larval instars at sub-lethal concentrations $\mathrm{LC}_{25}$ and $\mathrm{LC}_{50}$ (0.3 and $0.6 \mathrm{ppm}$, respectively) than mimic (1.1 and $1.5 \mathrm{ppm}$, respectively). But $\mathrm{LC}_{90}$ level was the same in the two IGRs. With respect to $4^{\text {th }}$ larval instar, match induced the higher toxic effect at all sub lethal doses than mimic. Biochemical analysis showed that match and mimic exhibited a severe reduction in the activities of the detoxification enzymes, acid phosphatase and esterases ( $\alpha$ and $\beta$ ), as compared to the control. The enzymatic activities were inhibited with the increase in the time posttreatment and also with the increase in dose. Therefore, the tested IGRs, tebufenozide and lufenuron, may be not detoxify by these enzymes.
\end{abstract}

Keywords: IGRs, Toxicity, Detoxification Enzymes, Spodoptera littoralis

\section{INTRODUCTION}

Among all cotton pests in Egypt, the cotton leaf worm, Spodoptera littoralis, is the most important. It is extremely polyphagous, and always appropriate to inflict excessive damage when it occurs in masses during certain years, commonly referred-to as "cotton worm monsoons (Amin and Salam, 2003). But the intensive use of broad-spectrum insecticides against $S$. littoralis has led the development of resistance to many registered pesticides for its control (Aydin and Gu" rkan, 2006) including IGRs (Temerak, 2002). IGRs differ widely from the commonly used insecticides, as they exert their insecticidal effects through their influence on development, metamorphosis and reproduction of the target insects by disrupting the normal activity of the endocrine system (Oberlander, et al., 1997). Their comprehensive effects and high selectivity as well as lower toxicity to non-target animals and the environment provide new tools for integrated pest management (Huang, et al., 2008).

IGRs can be grouped according to their mode of action as: chitin synthesis inhibitors and substances that interfere with the action of insect hormone (i.e. JHa, and ecdysteroids) (Tunaz, H. and N. Uygun, 2004). Tebufenozide (mimic) belongs to a class of insect growth regulators (IGRs), bisacylhydrazine ecdysteroid agonists, mimicking the natural insect moulting hormone 20hydroxyecdysone (20-E) (Dhadialla, et al., 1998). Several studies have reported on the sublethal effects of ecdysteroid agonists on different important pest species from various insect orders (Knight, 2000; Sun, et al., 2003). Due to a high specificity of ecdysteroid action 
against Lepidoptera, the use in integrated pest management (IPM) is possible since the compound is selective for several beneficial insects (Smagghe, et al., 2004). The lufenuron (match) is insect growth regulator that interferes with chitin synthesis, disrupt hormonal balance with exchanging in molting process, and inhibit the insect's growth (Oberlander and Silhacek, 1998).

The ineffectiveness of insect growth regulators in controlling insect pests, is attributed to the increased levels of enzymatic detoxification, (Biddinger, et al., 1996). There is a relationship between the increase of insecticide resistance and the activity of detoxification enzymes (Xin-Ju and Hui-Min, 2011). General esterases are a large and diverse group of hydrolases that hydrolyze numerous substrates, including esters, and have no specific substrate (Walker \& Mackness, 1983). A member of the esterase cluster probably plays a role in the detoxifcation of xenobiotic esters (Gacar and Tasksn, 2009). Increased esterase activity is a major mechanism of insecticide insensitivity or even resistance in many insect species (Zhou, et al., 2002).

Detoxification enzyme, acid phosphatase (ACP) in insects is generally demonstrated as the enzymatic defense against foreign compounds and play significant roles in maintaining their normal physiological functions ( $\mathrm{Li}$, and Liu, 2007). Phosphatases are capable of transphosphorylation in addition to hydrolysis. Phosphatases thus play an important role in the metabolism of carbohydrates, phospholipids and nucleotides. Acid phosphatase is important in biological processes that need high level of energy, such as development, growth, gamete's maturation and histolysis (Ray, et al., 1984).

The objective of this research was to assess the effect of tested IGRs: moulting hormone agonist, mimic (tebufenozide) and chitin synthesis inhibitors, benzoylphenylurea derivative, match (lufenuron) on the activity of esterases ( $\alpha$ and $\beta$ ) and acid phosphatases of both $2^{\text {nd }}$ and $4^{\text {th }}$ instar larvae of the cotton leafworm S. littoralis (Boisd.) These enzymes were selected as an indicator of insecticide detoxification is based on their importance in the insecticide resistance. Further, the study of enzymes involved in the detoxification mechanism will help us to introduce appropriate control measures such as combinations of insecticides or synergists for a better and effective control programme during outbreaks of the pest.

\section{MATERIAL AND METHODS}

\section{Test insect:}

The culture of the cotton leafworm, S. littoralis (Bosid) was initiated from freshly collected egg masses supplied from the division of cotton leafworm, of Plant Protection Research Institute, Dokki, Egypt, formed the basis of a culture designed to provide insects used in the present investigation. Larvae reared on castor leaves and maintained under laboratory conditions of $27 \pm 2 \mathrm{C}^{\circ}$ and R.H. $70 \pm 5 \%$ according to Bakr, et al., (2010).

\section{Tested Compounds:}

One moulting hormone agonist, ecdyson agonist, mimic $10 \%$ (tebufenozide) and the other chitin synthesis inhibitors, match $5 \%$ (lufenuron) were used in this study

\section{Susceptibility of cotton leafworm to IGRs:}

Newly moulted $2^{\text {nd }}$ and $4^{\text {th }}$ larval instars were segregated from the stock colony in clean glass Petri dishes and starved for 24 hrs. Pieces of castor been leaves, were treated by the leaf-dipping technique in the different concentrations of tested compounds according to Bakr, et al., (2010). Five concentrations of each IGRs (match and mimic) were used. Eighty of starved larvae, distributed in four replicates (20 larvae/replicate). Final mortality percentages of the treated and control larvae were recorded $24 \mathrm{hrs}$ posttreatment. The data of susceptibility test 
were subjected to probit analysis (Finney, 1971) to evaluate the values of $\mathrm{LC}_{25}, \mathrm{LC}_{50}$ and $\mathrm{LC}_{90}$.

\section{Estimation of enzymatic activities:}

Experiments were carried out to evaluate the effect of the tested IGRs residue on some detoxification enzymes of cotton leafworm. The castor bean leaves smeared with $\mathrm{LC}_{25}, \mathrm{LC}_{50}$ and $\mathrm{LC}_{90}$ ppm concentrations were fed to larvae as $2^{\text {nd }}$ and $4^{\text {th }}$ instars. Acid phosphatase and esterases ( $\alpha$ and $\beta$ ) were measured at different time intervals (6-12- 24-48 hrs) post treatment. The tested and control larvae were homogenized in distilled water (5 larvae $/ 5 \mathrm{ml}$ ) using a chilled glass Teflon tissue grinder for 3 minutes. Homogenates were centrifuged at 3500 r.p.m for 10 minutes at $2 \mathrm{C}^{\circ}$ in a refrigerated centrifuged. Phosphatases
(Acid and alkaline) and esterases ( $\alpha$ and $\beta$ ) were determined according to the methods described by Powell and Smith (1954) and Van Asperen (1962), respectively.

\section{RESULTS}

Toxicological activities of the tested IGRs against $2^{\text {nd }}$ and $4^{\text {th }}$ instar larvae are summarized in Table (1). Toxicity bioassays showed that match was the more toxic against $2^{\text {nd }}$ larval instars at sub-lethal concentrations $\mathrm{LC}_{20}$ and $\mathrm{LC}_{50} \quad(0.3$ and $0.6 \mathrm{ppm}$, respectively) followed by Mimic (1.1 and $1.5 \mathrm{ppm}$, respectively). Obtained results also, showed that the $\mathrm{LC}_{90}$ level was the same in match and mimic $(2.5 \mathrm{ppm})$. With respect to $4^{\text {th }}$ larval instar, match induced the higher toxic effect al all lethal doses than mimic.

Table 1: Toxicity data of the tested IGRs against $2^{\text {nd }}$ and $4^{\text {th }}$ larval instar of S. littoralis.

\begin{tabular}{|c|c|c|c|c|c|c|}
\hline \multirow{2}{*}{ IGRs } & \multicolumn{5}{|c|}{ Larval instar } \\
\cline { 2 - 7 } & \multicolumn{3}{|c|}{$2^{\text {nd }}$ instar } & \multicolumn{3}{|c|}{$4^{\text {th }}$ instar } \\
\hline \multirow{2}{*}{ Conc. (ppm) } & $\mathrm{LC}_{25}$ & $\mathrm{LC}_{50}$ & $\mathrm{LC}_{90}$ & $\mathrm{LC}_{25}$ & $\mathrm{LC}_{50}$ & $\mathrm{LC}_{90}$ \\
& & & & & & \\
\hline Match & 0.3 & 0.6 & 2.5 & 1.1 & 2 & 6.3 \\
\hline Mimic & 1.1 & 1.5 & 2.5 & 6.1 & 8.4 & 15 \\
\hline
\end{tabular}

The influence of the two IGRs, investigated. Results in Fig. (1A and B) mimic (tebufenozide) and match (lufenuron) on the activity of esterases ( $\alpha$ an $\beta$-esterases) and acid phosphatases of both of $2^{\text {nd }}$ and $4^{\text {th }}$ instar larvae of the cotton leafworm $S$. littoralis was showed inhibition in the activity of ACP in larvae $\left(2^{\text {nd }}\right.$ and $\left.4^{\text {th }}\right)$ treated with mimic with the increase in the time posttreatment and also with the increase in dose.

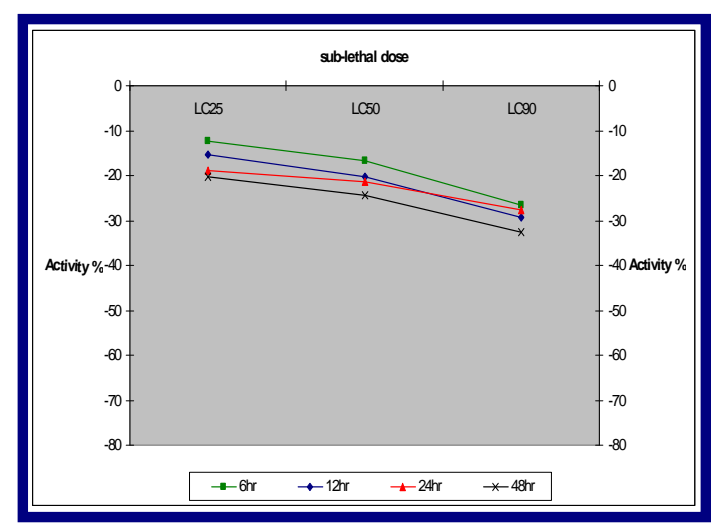

(A)

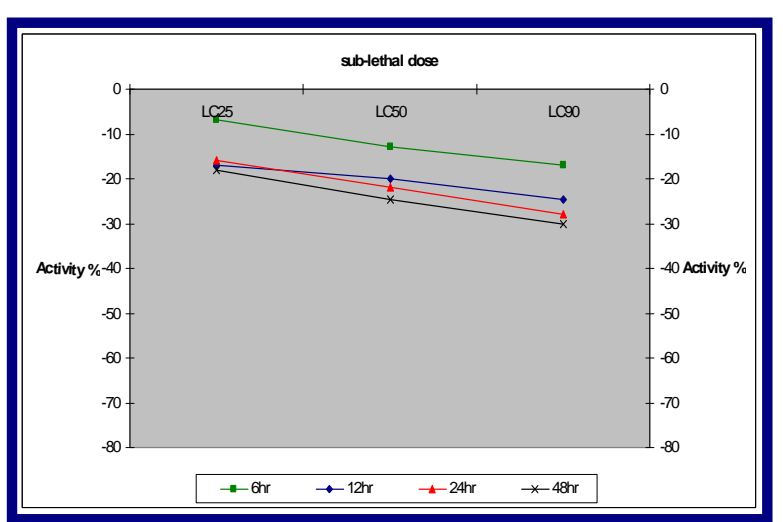

(B)

Fig. 1: Acid phosphatase activity of $2^{\text {nd }}(A)$ and $4^{\text {th }}(B) S$. littoralis larval instars treated with Sub-lethal doses of Mimic at different time intervals. 
The same effect of mimic on the activities of alpha esterase (Fig. 2A and $B$ for $2^{\text {nd }}$ and $4^{\text {th }}$ larval instars, respectively) and beta esterase (Fig. 3A and $B$ ) for $2^{\text {nd }}$ and $4^{\text {th }}$ larval instars, respectively) was observed as the activities of all enzymes decreased with the increase of doses and post time treatments.

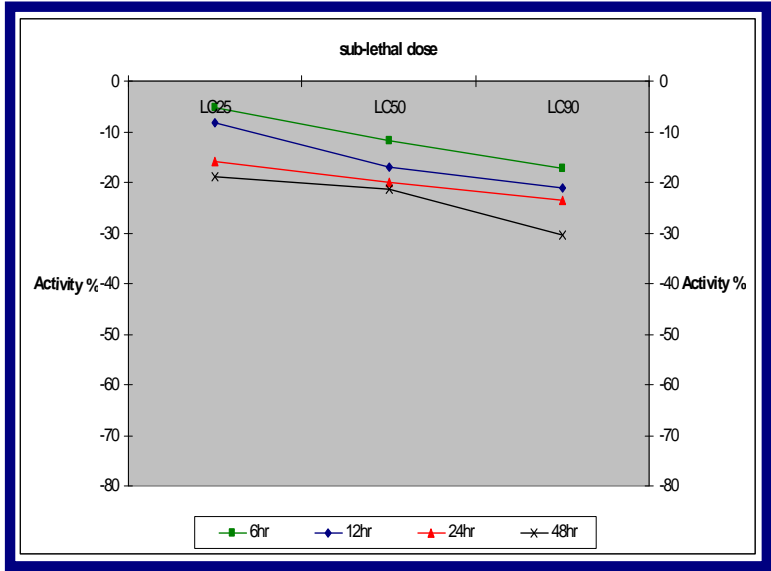

(A)

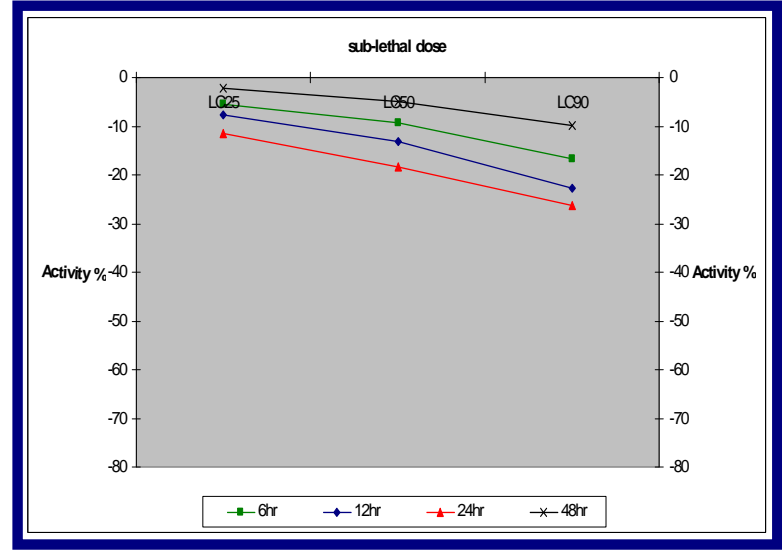

(B)

Fig. 2: $\alpha$-esterase activity of $2^{\text {nd }}(A)$ and $4^{\text {th }}$ (B) S. littoralis larval instars treated with Sub-lethal doses of Mimic at different time intervals.

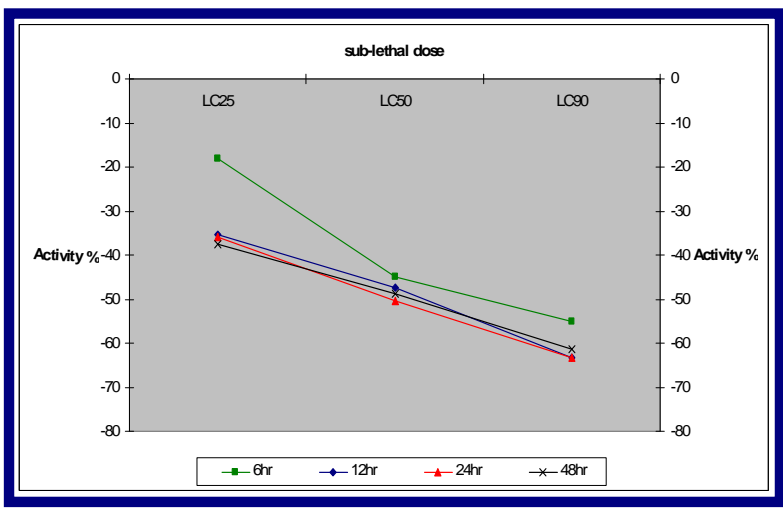

(A)

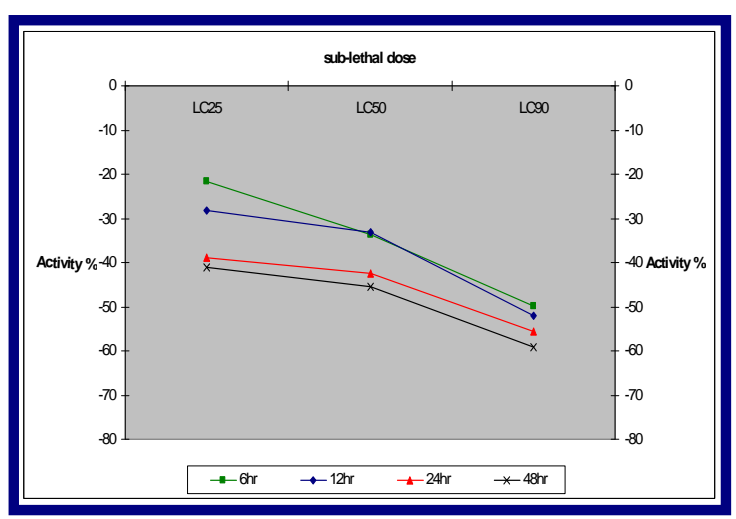

(B)

Fig. 3: $\beta$-esterase activity of $2^{\text {nd }}(\mathrm{A})$ and $4^{\text {th }}$ (B) S. littoralis larval instars treated with Sub-lethal doses of Mimic at different time intervals.

Results obtained in Fig. (4A) declared that treated $2^{\text {nd }}$ larval instar with match induced a decreasing in acid phosphatase activity as the dose increase and the time post-treatment increase. Treated $4^{\text {th }}$ larval instar with sub-lethal doses showed a reduction in the activity of the same enzyme (Fig. 4B). The activities of alpha esterase (Fig. $5 \mathrm{~A}$ and
B) in $2^{\text {nd }}$ and $4^{\text {th }}$ larval instars, respectively decreased also as the time post-treatment increase and with the increasing of the doses of match. The same result of sever reduction in the activity of beta esterase was observed in case of treatment of $2^{\text {nd }}$ and $4^{\text {th }}$ larval instars (Fig. $6 \mathrm{~A}$ and B, respectively). 


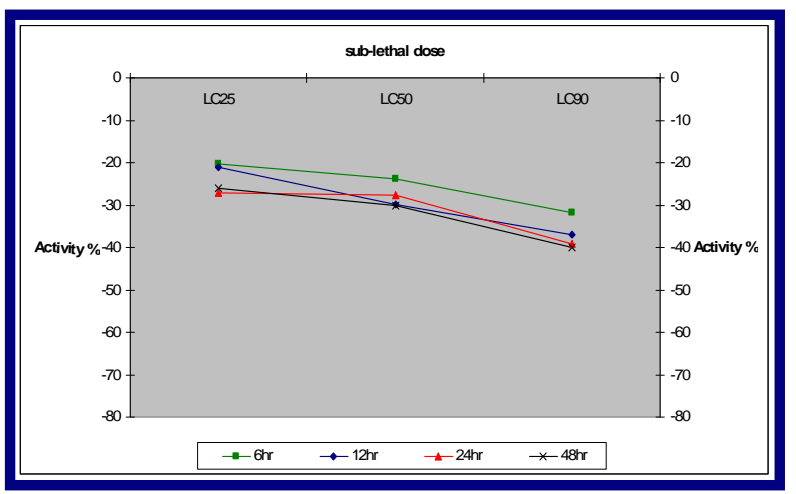

(A)

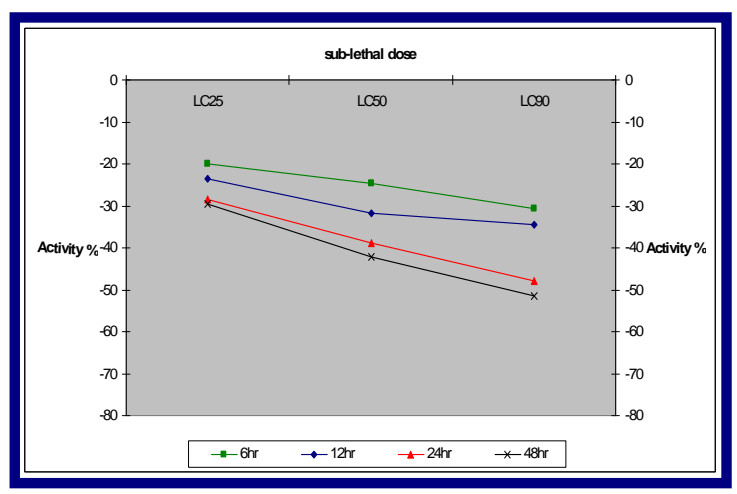

(B)

Fig. 4: Acid phosphatase activity of $2^{\text {nd }}$ (A) and $4^{\text {th }}$ (B) S. littoralis larval instars treated with Sub-lethal doses of Match at different time intervals.

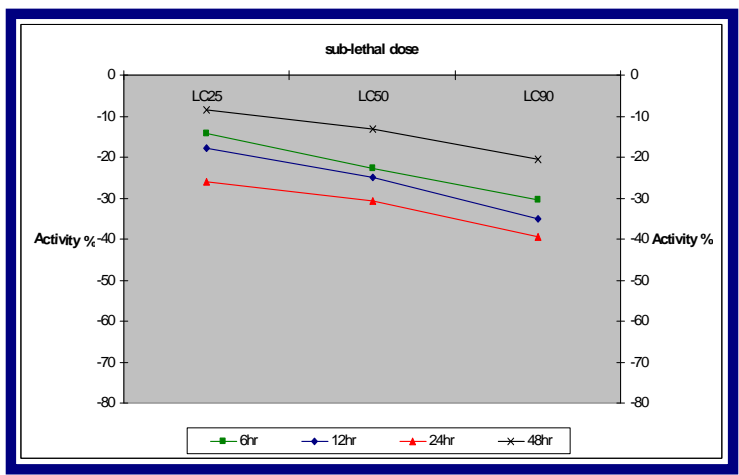

(A)

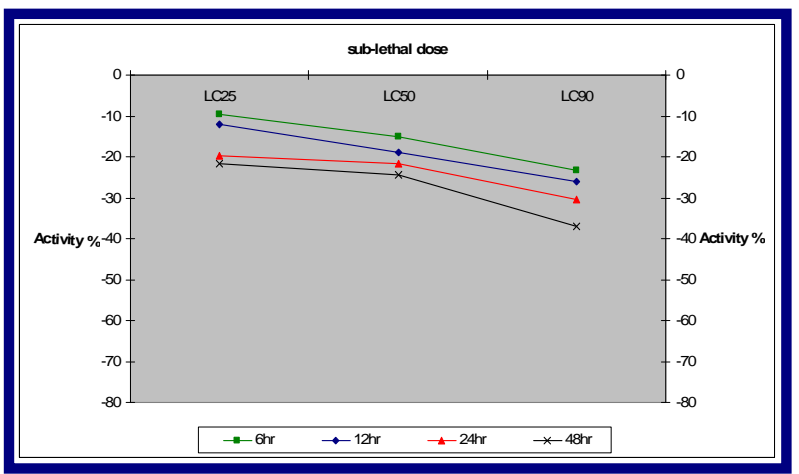

(B)

Fig. 5: $\alpha$-esterase activity of $2^{\text {nd }}(\mathrm{A})$ and $4^{\text {th }}$ S. littoralis larval instars treated with Sub-lethal doses of Match at different time intervals.

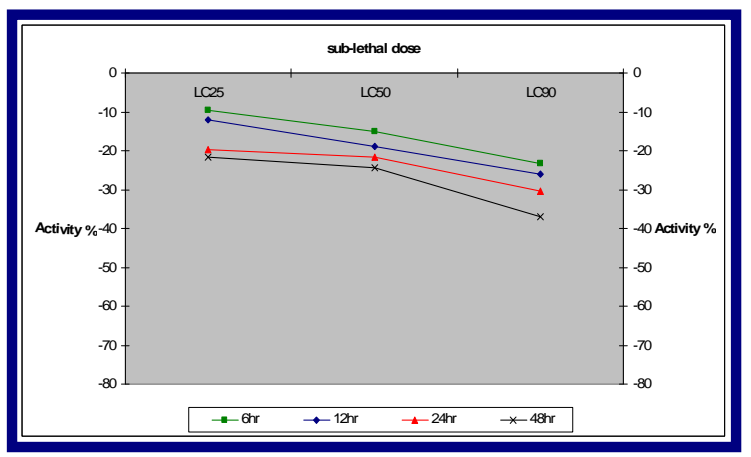

(A)

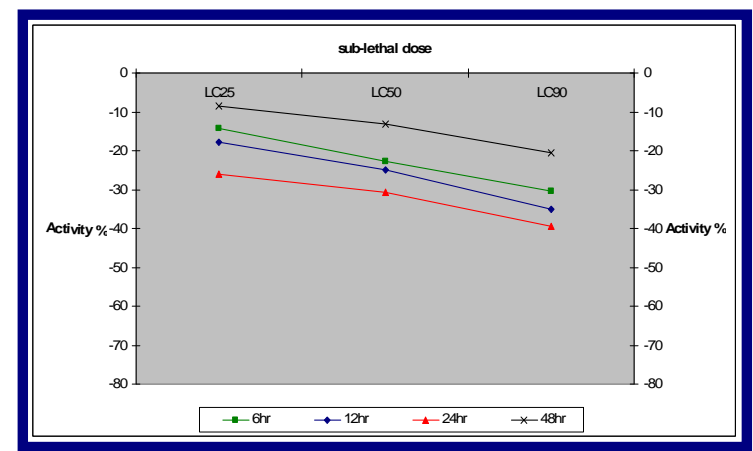

(B)

Fig. 6: $\beta$-esterase activity of $2^{\text {nd }}(\mathrm{A})$ and $4^{\text {th }}(\mathrm{B})$ S. littoralis larval instars treated with Sub-lethal doses of Match at different time intervals.

\section{DISCUSSION}

These results revealed that match was more toxic against the $2^{\text {nd }}$ and $4^{\text {th }}$ larval instars of $S$. littoralis at $\mathrm{LC}_{20}$ and $\mathrm{LC}_{50}$ than mimic and their toxicity increase depending on the concentration and the time after treatment. Lethal concentration with 20,50 and $90 \%$ kill values were used in the evaluation of their biochemical activity against two different detoxifying enzyme systems. Generally, effect of IGRs on detoxification enzymes in large group of pests was tested by many authors. El-Bermawy, (1994) had 
perceived suppression in acid phosphatase activity in larval, pupal and adult stage of Musca domestica treated with BAY SIR 8514 and pyriproxyfen. The sublethal effects of methoxyfenozide on detoxification enzymes in Spodoptera litura were also studied by Jian-jun, et al., (2009). After exposure to methoxyfenozide at $\mathrm{LC}_{10}$ for $24 \mathrm{hrs}$ and $\mathrm{LC}_{30}$ for 48 and $96 \mathrm{hrs}$, the activities of esterase were significantly increased compared with control. The activities of microsomal multifunctional oxidase and glutathione S-transferases were also significantly enhanced when $3^{\text {rd }}$ instar larvae were treated with methoxyfenozide at $\mathrm{LC}_{10}$ for $24 \mathrm{~h}$ and $\mathrm{LC}_{30}$ for $96 \mathrm{hrs}$, respectively. Assar, et al., (2010) reported that match induced increase in the activity of acid phosphatase while mimic induced a significant reduction in the same enzyme in the house fly, Musca domestica. Our finding agree with the results were found by Bakr, et al., (2010). They studied the effect of the sublethal doses $\mathrm{LC}_{25}, \mathrm{LC}_{50}$ and $\mathrm{LC}_{90}$ of flufenoxuron (Cascade) on the activity of detoxification enzymes, acid phosphatase and the non- specific esterases ( $\alpha, \beta$ esterases), of $2^{\text {nd }}$ and $4^{\text {th }}$ larval instars of $S$. littoralis. Their results showed that the activity of all enzymes decreased significantly in treated larvae at different times intervals post treatments.

Detoxification enzymes in insects are generally demonstrated as the enzymatic defense against foreign compounds and play a significant roles in maintaining their normal physiological functions ( $\mathrm{Li}$ and Liu, 2007). Our results suggest that the two tested IGRs; moulting hormone agonist, mimic (tebufenozide) and chitin synthesis inhibitors, match (lufenuron) worked more or less in a similar manner on the activity of the tested detoxification enzymes acid phosphatase and esterases ( $\alpha$ - an $\beta$ esterases). There activities were dependent on the time and the pesticide dose. Generally, match and mimic exhibited a severe (high significant) reduction in the activities of all enzyme as compared to the control.

The primary routes of insecticide resistance in all insects are alterations in the insecticide target site or changes in the rate at which the insecticide is detoxified. So far esterases, are known to be involved in the detoxification of the major groups of insecticides (Zhou et al., 2002; Herron, et al., 2004 and Pethuan, et al., 2007). Also acid phosphatase (ACP) plays an important role in the detoxification process of toxic compounds entering the body (Zheng, et al., 2007). The insect esterases can either cause broad-spectrum resistance to various insecticides through rapid binding and slow turnover of insecticide molecules (i.e.,sequestration) or cause narrow-spectrum resistance to a very restricted range of insecticides containing a common ester linkage, such as malathion, through rapid metabolism of the insecticides ( Karunaratne, et al., 1995).

The suppression of detoxification enzymes indicated that these enzymes play no role in the detoxification of tested compounds and may be increase the susceptibility of insect pest to these insecticides (Abd-Elaziz and El-Siad, 2009). In conclusion, our results indicated that the tested IGrs tebufenozide and lufenuron induced a reduction in the activities of acid phosphatase and alpha and beta esterases. Therefore, the tested IGRs, tebufenozide and lufenuron , may be not detoxify by these enzymes.

\section{REFERENCES}

Abd El-Aziz, M. F. and El-Sayed, Y.A. (2009). Toxicity and biochemical efficacy of six essential oils against Tribolium confusum (du val) (Coleoptera: Tenebrionidae). Egypt. Acad. J. biolog. Sci., 2 (2): $1-11$.

Amin, A and Salam, I. (2003). Factors stimulating the outbreaks of the cotton leafworm in Assuit Governorate. Bel Twide Cotton Conferences, Nashville, TN-January, 6(10): 1420-1422. 
Assar, A.A.; Abo El-Mahase, M.M.; Khalil, M.E. and. Mahmoud, S.H (2010). Biochemical effects of some insect growth regulators on the house fly, Musca domestica (Diptera: Muscidae). Egypt. Acad. J. biolog. Sci., 2(2): 33- 44.

Aydin, M.H. and Gü rkan, M.O. (2006). The efficacy of spinosad on different strains of $S$. littoralis (Boisduval) (Lepidoptera: Noctuidae). Turk. J. Biol., 30: 5-9.

Bakr, R.F.; El-barky, N.M.; Abd Elaziz, M.F. and. Abd El-Halim, H.M (2010). Effect of Chitin synthesis inhibitors (flufenoxuron) on some biological and biochemical aspects of the cotton leaf worm Spodoptera littoralis Bosid (Lepidoptera: Noctuidae). Egypt. Acad. J. biolog. Sci., 2 (2): $43-56$.

Biddinger, D. J.; Hull, L. A. and Mcpheron, B. A. (1996). Crossresistance and synergism in azinphosmethyl resistant and susceptible strains of tufted apple bud moth (Lepidoptera: Tortricidae) to variousinsect growth regulators and avarmectin. J. Econ. Entomol., 89: 274-287.

Chuan-Ling, Q.; Hemingway, J. and Xuan, L. (2003). Quantitative differences between populations of Culex quinquefasciatus in both the esterases $\alpha$ and $\beta$ involved in insecticide resistance. Acta Entomologica Sinica, 46 (1): 11-17.

Dhadialla, T.S.; Carlson G.R. and Le, D.P. (1998). New insecticides with ecdysteroidal and juvenile hormone activity. Annual Review of Entomology, 43:545-569.

El-Bermawy, S.M.; Hassanein, A.H.M.; Bakr, R.F.A. and Abdel-Razik, N.A. (1989). Activity of some insect growth regulators (IGRs) on Tribolium confusum Jacquelin Duval. J. of the faculty of education, 14: 527- 558.

Finney, D.J. (1972). Propit analysis. A statistical treatment of the sigmoid response curve. 7th Ed., Cambridge Univ. Press, England.

Gacar, F. and Tasksn, V. (2009). Partial base sequence analysis of MdaE7 gene and ali-esterase enzyme activities in field collected populations of housefly (Musca domestica L.) from Mediterranean and Aegean Regions of Turkey. Pestic. Biochem. Physiol., 94: 86-92.

Herron, G.; Cottage, E.; Wilson, L. and Gunning, R. (2004). nsecticide resistance in cotton aphid (Aphis gossypii): results and management options after seasons 2002/2003 and 2003/2004. In Crop Protection "Quality Cotton" - A Living Industry. $12^{\text {th }}$ Australian Cotton Conference, 10$12^{\text {th }}$ August.

Huang, Q.; Kong, Y.; Liu, M.; Feng, J. and Yang, L. (2008). Effect of oxadiazolyl $3(2 \mathrm{H})$-pyridazinone on the larval growth and digestive physiology of the armyworm, Pseudaletia separate. Journal of Insect Science. 8(19):7pp.

Jian-jun, W. and TIAN, D. (2009). Sublethal Effects of Methoxyfenozide on Spodoptera litura (Fabricius). Cotton Science, 21(3): 212-217.

Karunaratne, S. H. P. P.; Hemingway, J.; Weerasinghe, I. S.; Jayawardena, K. G. I.; Dassanayaka, V. and Vaughan, A. (1995). Kinetic and molecular differences in the amplified and nonamplified esterases from insecticide-resistant and susceptible Culex quinquefasciatus mosquitoes. Journal of Biological Chemistry, 270: 31124 -31128.

Knight, A.L. (2000). Tebufenozide targeted against codling moth (Lepidoptera: Tortricidae) adults, eggs and larvae. Journal of Economic Entomology, 93:1760-1767.

LI, X-Z and LIU, Y-H. (2007). Diet influences the detoxification enzyme activity of Bactrocera tau (Walker) (Diptera: Tephritidae). Acta Entomologica Sinica. 50 (10): 989-995. 
Oberlander, H.; Silhacek, D.L.; Shaaya, E. and Ishaaya, I. (1997). Current status and future perspectives of the use of insect growth regulators for the control of stored product pests. J. Stored Prod. Res., 33:

Oberlander, H. and Silhacek, D.L. (1998). New perspectives on the mode of action of benzoylphenyl urea insecticides. In: Ishaaya I, Degheele D, Editors. Insecticides with Novel Modes of Action, pp: 92-105.

Pethuan, S., Jirakanjanakit, N.; Saengtharatip, S.; Chareonviriyaphap, T.; Kaewpa, D. and Rongnoparut, P. (2007). Biochemical studies of insecticide resistance in Aedes (Stegomyia) aegypti and Aedes (Stegomyia) albopictus (Diptera: Culicidae) in Thailand. Tropical Biomedicine, 24(1): 7-15.

Powell, M.E.A. and Smith, M.J.H. (1954). The determination of serum acid and alkaline phosphatase activity with 4aminoan-tipyrine. J. Clin. Pathol., 7: 245-248.

Ray, A.; Rao, C.G.P.; Srivevi, R. and Ramamurty, P.S. (1984): Changes in acid phosphatase activity in Spodoptera litura (Lepi: Noctuidae) during the post embryonic and adult development . Entomol., 9(3): 161-167.

Retnakaran, A.; Granett, J. and Ennis, T. (1985). Insect growth regulators. In Comprehensive Insect Physiology Biochemistry and Pharmacology: Kertut. G.A. and Gilbert, L.I. Eds., 12: 529-601.

Santos, C.D. and Terra, W.R. (1984). Plasma membrane-associated amylase and trypsin: intracellular distribution of digestive enzymes in the midgut of the cassava hornworm, Erinnyis ello. Insect Biochemistry, 14: 587- 595.

Smagghe, G.; Bylemans, D.; Medin, P.; Budia, F.; Avilla, J. and Viñuela, E. (2004). Tebufenozide distorted codling moth larval growth and reproduction, and controlled field populations. Ann. appl. Biol , 145:291-298.
Sun, X. and Song, Q.; Barrett, B. (2003). Effect of ecdysone agonists on vitellogenesis and the expression of EcR and USP in codling moth (Cydia pomonella). Archives of Insect Biochemistry and Physiology, 52:115129.

Temerak, S.A. (2002). Historical record of cotton leafworms (Spodoptera littoralis) resistance to conventional insecticides in the field as influenced by resistance programs in Egypt from 1950-2002. Resistant pest management , 12(1):33-36.

Tunaz, H. and Uygun, N. (2004). Insect growth regulators for insect pest control. Turkish J. Agriculture and Forestry, 28: 337-387.

Van Asperen, R. (1962): A study of house fly esterase by means of sensitive colourimetric method. J. Insect. Physiol., 8: 401-416.

Walker, C.H. and Mackness, M.I. (1983). Esterases: problems of identification and classification. Biochemical Pharmacology, 32: 3265-3269.

Xin-Ju G. and Hui-Min, S. (2011). Resistance selection with fenpropathrin and the change of detoxification enzyme activities in Tetranychus urticae Koch (Acari: Tetranychidae). Acta Entomologica Sinica, 54 (1): 64-69.

Zheng, Y.Z.; Lan, W.S.; Qiao, C.L.; Mulchandani, A. and Chen, W. (2007). Decontamination of vegetables sprayed with organophosphate pesticides by organophosphorus hydrolase and carboxylesterase (BI). Applied Biochemistry and Biotechnology, 136(3): 233-242.

Zhou, X.; Scharf, M.E.; Parimi, S.; Meinke, L.J.; Wright, R.J.; Chandler, L.D. and Siegfried, B.D. (2002). Diagnostic assays based on esterasemediated resistance mechanisms in western corn rootworms (Coleoptera: Chrysomelidae). Journal of Economic Entomology, 95: 1261-266. 


\section{ARABIC SUMMERY}

نثاط بعض الإنزيمات في إزالة السموم من يرقات دودة ورق القطن المعاملة ياثنين من منظمات نمو الحشرات

رضا فضيل على بكر 1\&،منى قوزى عبدالعزيز22 ، نهاد محمد البرقى²، محمد عواد33 ، هشام محمد عبدالحليم²

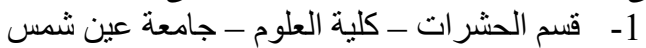

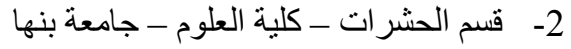

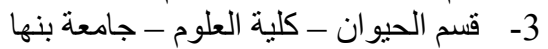

4- قسم الاحياء - كلية العلوم - جامعة الملك خالد - ابها ـ المملكة العربية السعودية

تتاولت هذه الدر اسة حساسية العمر اليرقي الثاني و الرابع من دودة ورق القطن الكبرى سبودوبتر اليتور اليز لاثثين

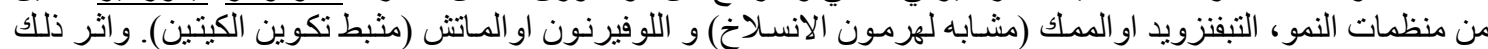

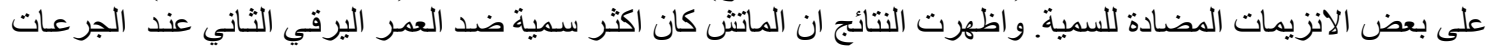

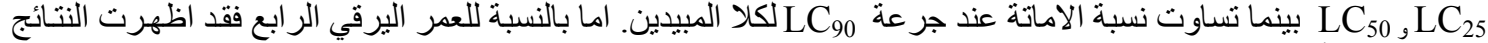

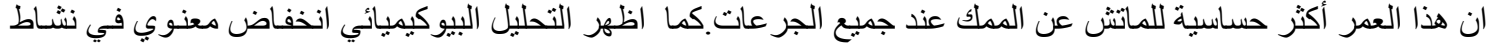

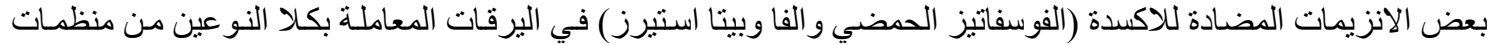

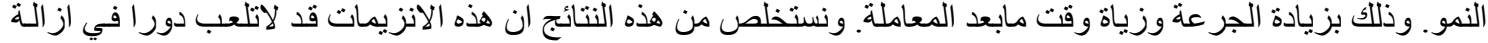
التسمم بهذه الانو اع من منظمات النمو. 